\title{
PELAKSANAAN PROGRAM REMEDIAL PADA MATA PELAJARAN BAHASA INDONESIA SISWA KELAS VIII DI SMP IT IQRA' KOTA BENGKULU
}

\author{
Extis Yuli Astuti, Didi Yulistio, dan Arono \\ Program Studi Pendidikan Bahasa Indonesia \\ Jurusan Pendidikan Bahasa dan Seni \\ FKIP Universitas Bengkulu \\ gm290395@yahoo.com
}

\begin{abstract}
Abstrak
Penelitian ini bertujuan untuk mendeskripsikan pelaksanaan remedial mata pelajaran Bahasa Indonesia dan faktor-faktor yang menyebabkan siswa mengalami remedial. Penelitian ini menggunakan pendekatan kualitatif dengan subjek siswa kelas VIII. Pengumpulan data dilaksanakan dengan observasi dan wawancara. Teknik analisis data yang digunakan adalah reduksi data, display data dan penarikan kesimpulan. Berdasarkan hasil penelitian dapat disimpulkan bahwa dalam pelaksanaan program remedial waktu pelaksanaan program remedial dilaksanakan dalam waktu satu minggu. Jumlah siswa yang melaksanakn remedial sebanyak 33 siswa. Metode yang digunakan dalam melaksanakan program remedial, yaitu pemberian tugas secara mandiri yang dikerjakan di rumah masingmasing. Faktor-faktor yang menyebabkan siswa remedial mencakup (1) faktor internal yang meliputi 5 aspek yaitu kebiasaan belajar, percaya diri, sikap terhadap belajar, menyimpan perolehan hasil belajar dan menggali hasil belajar yang tersimpan, dan (2) faktor eksternal, yaitu aspek kebijakan penilaian
\end{abstract}

\section{Kata kunci: Pelaksanaan program remedial}

\begin{abstract}
The purpose study is to describe implementation remedial subjects indonesia language and factors that cause students experience remedial. This research use qualitative approach with the subject students class VIII. Data collection implemented with observation and interview. Data analysis technique used is data reduction, display data, and conclusion. Bised on the results research can be concluded that in implementation remedial execution time remedial held during one week. The number of students that implement remedial as much 33 students. Method used in carrying out remedial that is giving task done on independent at home each. factors that cause students experience remedial includes (1) internal factors which cover 5 aspect that is study habits, confidence, attitude toward learning, save the acquisition of learning result, and digging out stored learning result, and external factor that is aspect assessment policy.
\end{abstract}

Keywords: Implementation of remedial program

\section{PENDAHULUAN}

Pendidikan adalah usaha yang dilakukan untuk mewujudkan proses pembelajaran yang bertujuan untuk mengembangkan kemampuan dan keterampilan dan memaksimalkan potensi siswa. Pendidikan berperan untuk mengembangkan kualitas sumber daya 
manusia (SDM). Dalam kegiatan pembelajaran guru tidak hanya sekedar menyampaikan materi pelajaran saja, namun guru harus dapat memahami karakteristik peserta didiknya. Setiap anak dilahirkan dengan kemampuan yang berbeda-beda, sehingga guru tidak dapat memaksakan semua siswa untuk memiliki kemampuan yang sama dalam memahami materi pelajaran.

Program remedial dilakukan untuk membantu siswa memenuhi kekurangan dalam kriteria ketuntasan belajar. Program remedial sangat diperlukan untuk meningkatkan daya serap siswa dalam memahami materi pelajaran yang belum tuntas (Depdiknas, 2003:17). Apabila sebagian besar siswa telah mencapai penguasaan tuntas terhadap materi yang diberikan kepadanya, maka guru dapat melanjutkan pada materi selanjutnya, tetapi jika belum maka perlu diakan remedial (Ischak,1987:3).

Menurut Tarigan (1989:21), program remedial hakikatnya adalah pemberian bantuan bagi peserta didik yang mengalami kesulitan belajar. Program remedial dapat diartikan sebagai suatu tindakan pembelajaran yang bersifat mendiagnosis dan memberikan perlakuan untuk memperbaiki atau menjadikan lebih baik. Program remedial merupakan salah satu tindakan berupa pembelajaran ulang yang diberikan setelah usainya kegiatan pembelajaran sebagai bantuan kepada siswa yang belum mencapai ketuntasan.

Dalam proses pembelajaran, seorang guru tentu bertanggung jawab untuk membantu dan membimbing siswa untuk memperoleh hasil belajar yang optimal. Seorang guru diharapkan untuk dapat menciptakan situasi pembelajaran yang efektif, efisien, dan relevan agar hal ini dapat tercapai maka guru harus memiliki kompetensi yang beraneka ragam. Dapat dikatakan bahwa remedial ini merupakan bagian yang integral dari suatu proses pembelajaran yang menghendaki ketuntasan.

Program remedial hakikatnya dilakukan untuk membantu siswa memenuhi kekurangan dalam kriteria ketuntasan belajar sehingga siswa mampu melanjutkan jenjang berikutnya (Kemendiknas, 2010:37).

Kesimpulannya bahwa program remedial merupakan solusi untuk membantu siswa mencapai kriteria ketuntasan minimum karena dalam sistem penilaian acuan kriteria berasumsi bahwa hampir semua orang bisa belajar apa saja namun dengan waktu yang berbeda.

Penelitian ini bertujuan untuk mendeskripsikan pelaksanaan program remedial dan faktor-faktor penyebab dilaksanakan program remedial pada mata pelajaran bahasa Indonesia kelas VIII di SMP IT IQRA' Kota Bengkulu.

Berdasarkan uraian di atas, maka penulis tertarik melakukan penelitian mengenai pelaksanaan program remedial pada mata pelajaran bahasa Indonesia kelas VIII SMP IT IQRA'.

\section{METODE}

Penelitian ini menggunakan pendekatan kualitatif dengan metode deskriptif. Penelitian kualitatif merupakan penelitian yang menggunakan latar alamiah, dengan maksud menafsirkan fenomena yang terjadi dan dilakukan dengan jalan melibatkan berbagai metode yang ada (Moleong, 1998:5). Metode deskriptif yaitu satu kaidah upaya pengolahan data yang memusatkan perhatian kepada masalah-masalah aktual, sebagaimana adanya pada masa sekarang, pada saat penelitian dilakukan (Susetyo, 2015:11). Penelitian kualitatif deskriptif adalah penelitian yang menggunakan latar belakang ilmiah dengan maksud menafsirkan fenomena yang terjadi yang berpusat pada masalah-masalah aktual 
sebagaimana adanya pada masa sekarang,pada saat penelitian dilakukan.

Data dalam penelitian ini yaitu adalah seluruh informasi dan keterangan mengenai pelaksanaan pembelajaran remedial mata pelajaran bahasa Indonesia kelas VIII SMP IT IQRA' Kota Bengkulu. Sumber data dalam penelitian ini adalah proses pelaksanaan program remedial siswa kelas VIII SMP IT IQRA' Kota Bengkulu dan guru bahasa Indonesia kelas VIII.

Teknik pengumpulan data dalam penelitian ini menggunakan teknik observasi dan wawancara. Teknik observasi yang digunakan oleh penulis adalah observasi non partisipan, yang digunakan untuk mengumpulkan data proses kegiatan pembelajaran sastra dengan menggunakan pendekatan saintifik. Observasi non partisipan adalah observasi yang menjadikan peneliti sebagai penonton atau penyaksi terhadap gejala atau kejadian yang menjadi topik penelitian. Dalam observasi jenis ini peneliti melihat atau mendengarkan pada situasi sosial tertentu tanpa partisipasi aktif di dalamnya (Emzir, 2014:40). Teknik wawancara yang digunakan dalam penelitian ini adalah wawancara tidak terstruktur. Sugiyono (2013:140) mengungkapkan bahwa wawancara tidak terstruktur adalah wawancara yang bebas, maksudnya peneliti tidak menggunakan pedoman wawancara yang telah tersusun secara sistematis dan lengkap untuk pengumpulan datanya. Pedoman wawancara yang digunakan hanya berupa garis-garis besar permasalahan yang akan ditanyakan.

\section{HASIL PENELITIAN DAN PEMBAHASAN Hasil Penelitian \\ Pelaksanaan Remedial}

Pelaksanaan remedial di SMP IT IQRA' kota Bengkulu remedial dilaksanakan per kompetensi. Setelah satu kompetensi pembelajaran selesai dibahas atau dipelajari maka guru akan melaksanakan sebuah ulangan harian untuk siswa. Selesai ulangan dilaksanakan guru akan memeriksa hasil ulangan tersebut dalam beberapa hari karena, jumlah siswa yang banyak dan kegiatan guru mengajar yang padat. Penilaian yang dilakukan guru setelah remedial dilaksanakan yaitu dengan cara melihat ada tidaknya keseluruhan unsur-unsur berita yaitu $5 \mathrm{~W}+1 \mathrm{H}$ dalam teks berita yang telah dibuat siswa. Selain unsur-unsur berita yang harus ada, guru menilai kepaduan kalimat yang ditulis siswa dan pilihan kata yang dipilih oleh siswa. Padunya satu kalimat dengan kalimat lain sangatlah penting dalam sebuah teks berita sehingga dapat dibaca orang lain dengan nyaman pula. Jika tidak terdapat keterpaduan antarkalimat maka juga akan janggal jika kita membacanya. Pilihan kata yang dipilih juga sangatnya penting, kata yang terus diulang tidaklah efektif dalam sebuah teks kalimat.

\section{Waktu Pelaksanaan Remedial}

Berdasarkan penelitian yang telah peneliti lakukan, waktu remedial dilaksanakan selama satu minggu. Guru memberikan soal membuat sebuah teks berita dengan unsur-unsur berita yang lengkap tentang pelaksanaan pemeran senjata TNI yang dilaksanaan di Bengcollen Indah Moll seperti yang telah mereka lihat pada kunjungan mereka pada tanggal 3 Oktober 2017.

\section{a. Metode yang Digunakan}

Metode yang digunakan adalah metode pemberian tugas. Pemberian tugas dipilih oleh guru sebagai metode pelaksanaan remedial karena pemberian tugas dianggap oleh guru tidak terlalu merepotkan guru dan memerlukan waktu yang banyak. Dengan banyaknya kegiatan guru di sekolah maupun di luar sekolah 
metode pemberian tugas dianggap lebih tepat untuk digunakan.

1) Jumlah siswa

Jumlah seluruh siswa yang mengikuti remedial dari kelas $8^{\text {a }}$ hingga $8^{f}$ sebanyak 33 orang siswa, yaitu kelas $8^{a}$ dari jumlah siswa sebanyak 31 orang siswa yang mengikuti remedial sebanyak 5 orang siswa, kelas $8^{\mathrm{b}}$ dari jumlah siswa sebanyak 31 orang siswa yang mengikuti remedial sebanyak 6 orang siswa, kelas $8^{c}$ dari jumlah siswa sebanyak 31 orang siswa yang mengikuti remedial sebanyak 6 orang siswa, kelas $8^{\text {d }}$ dari jumlah siswa sebanyak 31 orang siswa yang mengikuti remedial sebanyak 7 orang siswa, kelas $8^{\mathrm{e}}$ dari jumlah siswa sebanyak 30 orang siswa yang mengikuti remedial sebanyak 5 orang siswa, dan kelas $8^{f}$ dari jumlah siswa sebanyak 30 orang siswa yang mengikuti remedial sebanyak 4 orang siswa.

2) Tempat pelaksanaan remedial

Karena waktu yang tidak memungkinkan siswa untuk melaksanakan remedial di sekolah sehingga siswa mengerjakan tugas remedial di rumah masing-masing.

\section{b. Faktor-Faktor Penyebab Siswa Remedial}

1) Faktor Internal

Berdasarkan hasil penelitian yang talah dilakukan entang faktor-faktor internal yang menjadi penyebab siswa remedial didapatkan haisl bahwa dari keseluruhan faktor internal tidak semua faktor menjadi penyebab siswa remedial tetapi ada 3 faktor yang menyebabkan siswa remedial yaitu faktor sikap terhadap belajar, faktor percaya diri siswa dan fakor kebiasaan belajar siswa.

2) Faktor Eksternal
Berdasarkan hasil penelitian yang telah dilakukan tentang faktor-faktor eksternal yang memperngaruhi siswa remedial, didapatka hasil bahwa dari kelima faktor eksternal tidak semua faktor menjadi penyebab siswa remedial. Dari hasil yang didapat diketahui bahwa faktor kebijakan penilaian yang menjadi faktor penyebab siswa remedial.

\section{c. Hasil Wawancara Guru}

1) Latar belakang

Masih banyak siswa yang mendapat nilai di bawah KKM membuat guru mengadakan remedial untuk memperbaiki nilai mereka agar nanti di rapotnya tidak merah.

\section{2) Persiapan}

Guru melakukan berbagai persiapan untuk melaksanakan remedial. Untuk membuat soal remedial pun guru memerlukan sebuah persiapan yang matang, tidak asal menunjuk soal untuk dikerjakan oleh siswa. Soal yang dibuat harus benar-benar sesuai dengan kebutuhan siswanya.

3) Materi

Materi yang dipilih guru dalam melaksakan program remedial disesuaikan dengan materi yang terakhir siswa pelajari. Karena dengan materi terakhir yang siswa pelajari maka bisa diketahui bahwa siswa belum memahami materi tersebut sehingga program remedial menggunakan materi yang terakhir mereka pelajari.

\section{Pembahasan}

Remedial dilakukan terhadap kompetensi dasar yang belum mencapai KKM. Pelaksanaan kegiatan remedial maksimal dilakukan sebanyak 3 kali atau dihentikan pada saat ketuntasan mencapai 
minimal $85 \%$. Pada pelaksanaan remedial guru melaksanakan remedia per kompetensi pembelajaran. Setelah guru selesai menjelaskan satu materi maka guru akan melaksanakan ulangan harian. Setelah itu didapat hasil siswa yang telah mencapai KKM dan siswa yang belum mencapai KKM. Siswa yang belum mencapai KKM maka diberikan program remedial berupa sebuah tugas dengan materi sesuai dengan yang mereka pelajari terakhir kali. Penilaian yang dilakukan guru setelah remedial dilaksanakan yaitu dengan cara melihat ada tidaknya keseluruhan unsur-unsur berita yaitu $5 \mathrm{~W}+1 \mathrm{H}$ dalam teks berita yang telah dibuat siswa. Selain unsur-unsur berita yang harus ada, guru menilai kepaduan kalimat yang ditulis siswa dan pilihan kata yang dipilih oleh siswa. Padunya satu kalimat dengan kalimat lain sangatlah penting dalam sebuah teks berita sehingga dapat dibaca orang lain dengan nyaman pula. Jika tidak terdapat keterpaduan antarkalimat maka akan janggal jika dibaca. Pilihan kata yang dipilih juga sangat penting, kata yang terus diulang tidaklah efektif dalam sebuah teks kalimat. Selain itu, tidak melakukan pemborosan kata dalam kalimat, kalimat dibuat seefesien mungkin dengan memilih kata-kata yang tepat sehingga tidak perlu menambahkan kata yang tidak perlu untuk ditambahkan. Jumlah siswa yang mengikuti remedial dari seluruh siswa kelas VIII sebanyak 33 orang siswa. yaitu kelas VIIla dari jumlah siswa sebanyak 31 orang siswa yang mengikuti remedial sebanyak 5 orang siswa, kelas VIIlb dari jumlah siswa sebanyak 31 orang siswa yang mengikuti remedial sebanyak 6 orang siswa, kelas VIIlc dari jumlah siswa sebanyak 31 orang siswa yang mengikuti remedial sebanyak 6 orang siswa, kelas VIIId dari jumlah siswa sebanyak 31 orang siswa yang mengikuti remedial sebanyak 7 orang siswa, kelas VIIle dari jumlah siswa sebanyak 30 orang siswa yang mengikuti remedial sebanyak 5 siswa, dan kelas VIIIf dari jumlah siswa sebanyak 30 orang siswa yang mengikuti remedial sebanyak 4 orang siswa.

Menurut Arifin (1995:228) teknik program remedial di antaranya 1) pemberian tugas, 2) diskusi, 3) tutor sebaya, dan 4) pembelajaran individual. Dari hasil penelitian yang telah dilaksanakan teknik yang digunakan guru dalam melaksanakan program remedial adalah teknik pemberian tugas. Tugas dapat diberikan secara individu maupun kelompok. Keuntungan penggunaan metode ini antara lain, peserta didik lebih memahami kemampuan dan kelemahan dirinya sendiri, peserta didik dapat memperluas dan memperdalam materi yang dipelajari, peserta didik dapat memperbaiki cara-cara belajar yang telah dilakukan, dan terdapat kemajuan belajar peserta didik baik secara individual maupun kelompok. Dari hasil penelitian yang telah dilakukan tugas diberikan kepada siswa secara individu.

1. Faktor-faktor penyebab siswa remedial ada 2 yaitu (1) faktor internal diantarnya (a) kebiasaan nelajar, (b) rasa percaya diri, (c) sikap terhadap belajar, (d) menggali hasil belajar yang tersimpan, (e) menyimpan hasil belajar. (2) faktor eksternal, yaitu kebijakan penilaian.

2. Hasil Wawancara Guru

Setiap guru berharap siswanya dapat mencapai penguasaan kompetensi yang telah ditentukan. Tetapi, pada kenyataannya masih ada beberapa siswa yang masih mendapakan nilai di bawah KKM hal tersebut yang melatarbelakangi guru melakukan program remedial agar siswa tersebut dapat menambah nilainya yang masih kurang. Dalam melaksanakan program remedial sebelumnya guru melakukan beberapa persiapan. Yang pertama guru melihat data nilai untuk mendata siswa yang nilainya sudah tuntas dan 
siswa yang nilainya belum mencapai KKM per kelas mereka, setelah itu guru membuat soal untuk anak-anak sesuai dengan materi terakhir yang mereka pelajari, kemudian mengumukan kepada anak-anak siapa saja yang nilainya kurang dan diperintahkan mengerjakan tugasnya baik di rumah maupun di sekolah sesuai kondisinya. Guru juga memberikan beberapa arahan perihal tugas yang diberikan, mulai dari cara mengerjakan, mengambil sumber, dan waktu prngumpulan tugas tersebut. Ada beberapa metode yang dalam pelaksanaan program remedial yang digunakan guru. Dari hasil peneillitian, guru menggunakan metode pemberian tugas secara individu kepada siswa. Tetapi, semua itu disesuaikan dengan kondisi kegiatan siswa jika waktunya tidak berdekatan dengan kegiatan lain guru memberikan tugas berupa soal-soal yang harus dikerjakan siswa di sekolah, tapi jika waktunya tidak memungkinkan maka diberikan tugas yang dikerjakan di rumah masingmasing. Metode pemberian tugas dipiih oleh guru karena metode pemberian tugas menurut guru lebih pasti, Penentuan materi untuk membuat soal remedial ditentukan guru dari materi terakhir yang telah siswa pelajari. Dari materi terakhir yang telah dipelajari dan dijadikan materi ulangan maka dari hasil ulangan yang sudah diperoleh dapat diketahui siswa yang belum mengusai materi pembelajaran. Dari hal itulah guru memberikan materi yang sama untuk program remedial dengan maksud siswa memahami materi tersebut sepenuhnya
Pelaksanaan program remedial di SMP IT IQRA dilakukan per kompetensi dasar. Waktu pelaksanaan program remedial dilaksanakan dalam waktu satu minggu. Jumlah siswa yang melaksanakan remedial sebanyak 33 siswa. Metode yang digunakan dalam melaksanakan program remedial yaitu pemberian tugas secara mandiri yang dikerjakan di rumah masingmasing. Setelah diaksanakannya program remedial hasil yang didapatkan adalah nilai siswa mengalami kenaikan dan telah mencapai kriteria ketuntasan minimum.

Faktor-faktor yang menyebabkan siswa remedial mencakup (1) faktor internal yang meliputi 5 aspek, (a) kebiasaan belajar siswa karena kebiasaan belajar siswa yang buruk yaitu mereka hanya belajar ketika akan diadakan ulangan, itu berarti setelah selesai pembelajaran di sekolah siswa tidak lagi mempelajari kembali materi yang telah diberikan di rumah mereka masing-masing, (b) percaya diri karena siswa tidak percaya diri saat menjawab ulangan dikarenakan kurangnya belajar sehingga siswa tidak mengetahui jawaban yang benar dan menimbulkan keraguan saat menjawab, (c) sikap terhadap belajar, kebanyakan siswa malas untuk belajar, (d) menyimpan hasil peroehan belajar, karena banyaknya materi dan masih banyak peajaran lain yang harus dipelajari juga membuat siswa kesuitan unuk menyimpan hasi perolehan belajar mereka, (e) menggali hasil belajar, karena kesuian dalam mengingat keseluruhan materi yang telah dipelajari maka membuat siswa kesulitan untuk mengingatnya kembali. dan (2) faktor eksternal yaitu aspek kebijakan penilaian, karena menurut siswa ketetapan kriteria ketuntasan minimum yang telah ditetapkan telalu tinggi.

\section{Saran}

Bagi guru sebaiknya melakukan analisis kesulitan siswa terlabih dahulu,

\section{Simpulan}

JURNAL ILMIAH KORPUS, Volume II, Nomor II, Agustus 2018 
yaitu menganalisis kompetensi dasar yang memang banyak belum dikuasai oleh siswa yang menyebabkan siswa tidak dapat mencapai nilai KKM.

Bagi instansi pendidikan sebaiknya pelaksanaan remedial dirancang dengan sungguh-sungguh disetiap sekolah karena program remedial sangatlah penting bagi siswa yang nilainya masih di bawah KKM.

Bagi siswa sebaiknya bersungguhsungguh dalam mengikuti program remedial dan melaksanakan setiap perintah guru dan mematuhi nasihatnya serta lebih giat belajar lagi agar nilai mereka menjadi lebih baik.

DAFTAR PUSTAKA

Arifin, Muyani. 1995. Pengembangan Program Pengajaran Bidang Studi
Kimia. Surabaya. Airlangga University Press.

Depdiknas. 2003. Kurikulum Berbasis Kompetensi Sekolah Menangah Pertama. Jakarta. Diknenum.

Emzir. 2014. Metode Penelitian Kualitatif Analisis Data. Jakarta: Rajawali Press. Ischak dkk. 1987. Program Pengajaran Remedial. Yogyakarta. Liberty.

Kemendiknas.2010.Seri Petunjuk Teknis

Pelaksanaan Pembelajaran dalam Implementasi KTSP di SMA. Direktorat Pembinaan SMA. Jakarta.

Sugiyono. 2013. Metode Penelitian Pendidikan Kombinasi. Bandung: Alfabeta.

Tarigan, Henry Guntur. 1989. Pengajaran Remedi Bahasa. Jakarta. Direktorat Jendral Pendidikan Tinggi Depdikbud. 